\title{
THE IMPORTANCE OF RESEARCH AND DEVELOPMENT EXPENDITURE FOR THE COMPETITIVENESS OF MANUFACTURING ENTERPRISES IN POLAND. THE APPLICATION OF PANEL MODELS
}

\author{
Maria M. Grzelak \\ University of Lodz, Lodz, Poland \\ e-mail:mgrzel@wp.pl \\ ORCID: 0000-0003-4353-9893
}

\section{Iwona Laskowska}

University of Lodz, Lodz, Poland

e-mail: ilaskow@uni.lodz.pl

ORCID: 0000-0002-1657-5541

\section{Elżbieta Roszko-Wójtowicz}

University of Lodz, Lodz, Poland

e-mail: elzbieta.roszko@uni.lodz.pl

ORCID: 0000-0001-9337-7218

(C) 2018 Maria M. Grzelak, Iwona Laskowska, Elżbieta Roszko-Wójtowicz

This is an open access article distributed under the Creative Commons Attribution-NonCommercial-NoDerivs license (http://creativecommons.org/licenses/by-nc-nd/3.0/)

DOI: 10.15611/eada.2018.3.01

JEL Classification: C23, E23, O30

\begin{abstract}
In contemporary research and economic discussions, a great deal of attention is paid to issues concerning the relationship between competitiveness and research and development (R\&D) activity. The measurement and assessment of the impact of R\&D activity are extremely difficult but at the same time very important, in particular for authorities determining the level of expenditure on R\&D and the method of spending public funds as well as for enterprises assessing the expected profits derived from R\&D. The main aim of the article is an attempt to quantify the impact of R\&D expenditure on three selected characteristics defining the competitiveness of manufacturing enterprises (gross value added, sold production and labour productivity). The analysis was carried out using panel models. The study makes use of statistical data published by the Central Statistical Office for individual divisions of manufacturing (Section C of the Polish Classification of Activities - PKD) in the years 2009-2016. The conducted analyses indicate that R\&D expenditure constitutes a significant determinant of the competitiveness of the analysed divisions of manufacturing.
\end{abstract}

Keywords: R\&D expenditure, competitiveness, manufacturing, panel models. 


\section{Introduction}

Under the conditions of progressing globalisation, only the countries and economies that are competitive can achieve success. An important factor determining the improvement of competitiveness is the development of science as well as technical, technological and organisational progress. This progress causes the emergence of new production methods, innovative forms of organising the production process and methods of human capital management. Therefore innovations are the main stimulus for the development of modern world economies [Walczak 2012, p. 75].

In theoretical terms, it has been proven that achieving a competitive advantage is possible only through innovative activities, and the ability of the industry to innovate and raise the technological level determines the competitiveness of the entire economy [Porter 1990]. The implemented innovative projects are often complicated and highrisk processes, hence not all the innovative activities are successful. The amount of accumulated knowledge and the ability to use it properly contribute to the improvement of the effectiveness of the innovative activities undertaken. Knowledge creation in the economy occurs primarily through research and development (R\&D). The Central Statistical Office (CSO - GUS) defines research and development activity as creative work carried out on a systematic basis in order to increase the stock of knowledge of mankind, culture and society, and the use of this knowledge to devise new applications. It involves three types of activities, that is basic research, applied research (including industrial) and experimental development. A visible element of novelty and the elimination of scientific and/or technical uncertainty, i.e. a solution to a problem not resulting from the present state of knowledge in an obvious way, distinguishes R\&D from other types of activities [GUS and US in Szczecin 2016, p. 14].

Expenditure on research and development activity is widely recognised as one of the most important characteristics defining innovativeness and the development efficiency of economies and enterprises [Bassanini, Scarpetta, Hemmings 2001; Bouis et al. 2011]. It is worth mentioning that $R \& D$ expenditure is a component of expenditure on innovative activity. In the light of these premise, it should be assumed that expenditure on research and development activity is of key importance for a country's development as it determines the degree of innovativeness and competitiveness of the economy.

The measurement of the effects of innovative activity, including research and development activity, though extremely difficult, is important for the authorities determining the level of R\&D expenditure and the method of spending public funds as well as for enterprises assessing the expected profits from R\&D activity and innovations.

The paper is an attempt to provide a quantitative description of the impact of $R \& D$ expenditure and innovation outlays on three selected characteristics defining the competitiveness of manufacturing enterprises (gross value added, sold production and labour productivity). Panel models are used as the analysis tool. The study 
covered the years 2010-2016. The year of 2009 was chosen as the starting point of research as it is the year preceding the implementation of the Europe 2020 strategy in the European Union Member States, which introduced changes in the priorities of the EU's policy of enhancing competitiveness oriented towards sustainable economic growth based on innovation. The analysis ends with 2016, which is dictated by the availability of the latest statistical data.

The study makes use of statistical data published by the Central Statistical Office for individual divisions of manufacturing (Section $\mathrm{C}$ of the Polish Classification of Activities - PKD) in 2009-2016. In relation to the research objective, a research hypothesis has been formulated that the increase in research and development expenditure is a significant determinant of raising the competitiveness of manufacturing enterprises.

According to M. Porter, the impact of innovative activity, including R\&D activity, conducted by enterprises from manufacturing divisions on their competitiveness is reflected by changes in labour and capital productivity [Porter 1990]. It is assumed that in the short-term the improvement of the competitiveness of manufacturing divisions is manifested in the increase in the value of sold production, while in the long-term in the growth of productivity.

In light of the above-presented considerations, it seems reasonable that in order to assess the impact of innovation on the competitiveness of manufacturing divisions in Poland, one should take into account, on the one hand, the level of $R \& D$ expenditure of enterprises from a given division, treating the said expenditure as capital used to create and introduce new solutions, and, on the other hand, the results achieved, measured by changes in value added, dynamics of sold production and changes in labour productivity [Witkowski, Weresa 2006, pp. 2002-2003].

An econometric analysis should be preceded by a short description of $R \& D$ expenditure in Poland (in general and in manufacturing enterprises) compared to other EU countries. The paper was divided into four main parts, logically connected with one another. The subsequent chapters, including the sections in the third part, allow for the successive exploration of the analysed issue. The structure of the paper enables a thorough assessment of the significance of R\&D expenditure for the competitiveness of manufacturing enterprises in Poland in the period 2010-2016. The third part is the most extensive, as it includes both the theoretical framework of panel models and the discussion concerning the conducted empirical research, including the results of estimating the parameters of the FEM and REM models.

\section{R\&D activity in Poland - selected indices}

Knowing that expenditure on research and development activity is of key importance for the growth of competitiveness and development of every country, it is worth investigating the changes that have taken place in this area in Poland. Table 1 presents basic indicators characterising research and development activity in 2009-2016. 
In the analysed period, positive changes were noted in Poland as the value of domestic internal expenditure on research and development increased by $97.8 \%$. The maximum expenditure, amounting to PLN 18.06 billion, was recorded in 2015. An increase in the intensity ratio of $R \& D$ activity, i.e. internal $R \& D$ expenditure expressed as a percentage of GDP, was also observed. For the years 2009-2016 that increase amounted to 0.30 percentage point compared to the increase of 0.04 percentage point in 2002-2008.

Table 1. Selected measures of R\&D activity in Poland in 2009-2016

\begin{tabular}{|c|c|c|c|}
\hline Year & $\begin{array}{c}\text { Internal expenditure } \\
\text { on R\&D in PLN billion }\end{array}$ & $\begin{array}{c}\text { R\&D expenditure as } \\
\text { a percentage of GDP (\%) }\end{array}$ & $\begin{array}{c}\text { Internal expenditure on R\&D } \\
\text { per capita in PLN }\end{array}$ \\
\hline 2009 & 9.07 & 0.67 & 238 \\
\hline 2010 & 10.42 & 0.72 & 270 \\
\hline 2011 & 11.69 & 0.75 & 303 \\
\hline 2012 & 14.35 & 0.88 & 372 \\
\hline 2013 & 14.42 & 0.87 & 375 \\
\hline 2014 & 16.17 & 0.94 & 420 \\
\hline 2015 & 18.06 & 1.00 & 470 \\
\hline 2016 & 17.94 & 0.97 & 467 \\
\hline
\end{tabular}

Source: [GUS and US in Szczecin 2017, p. 15].

In 2016 the share of R\&D expenditure in GDP in Poland in relation to the EU-28 was lower by 1.06 percentage point, which means that our country ranked 19th among the European Union countries.

The intensity ratio of R\&D activity for Poland was over two times lower than for the entire European Union [GUS and US in Szczecin, 2018, p. 25]. In 2015, in Poland as in Slovakia, the share of internal expenditure on research and development in GDP exceeded 1\% for the first time. However, the 3\% threshold determined for this index in the EU strategic documents was only achieved by Sweden, Austria and Denmark. In Poland the index showed significant growth in the analysed years of as much as $44.8 \%$, but the distance from the EU remains large. It should be noted that, according to the National Development Strategy, the share of expenditure on R\&D in GDP should by 2020 reach the level of $1.7 \%$, which means that R\&D expenditure ought to amount to over PLN 35 billion, i.e. more than twice as much as in 2016.

Internal expenditure on R\&D activity per 1 inhabitant in 2016 amounted to PLN 467, which gave Poland 21st position among the EU-28 countries, where the average value of expenditure was EUR 512.3. This index also shows the enormous gap between Poland and the highly developed countries.

In the statistical analysis of R\&D expenditure, apart from the level and structure of spending, sources of financing should also be included. 


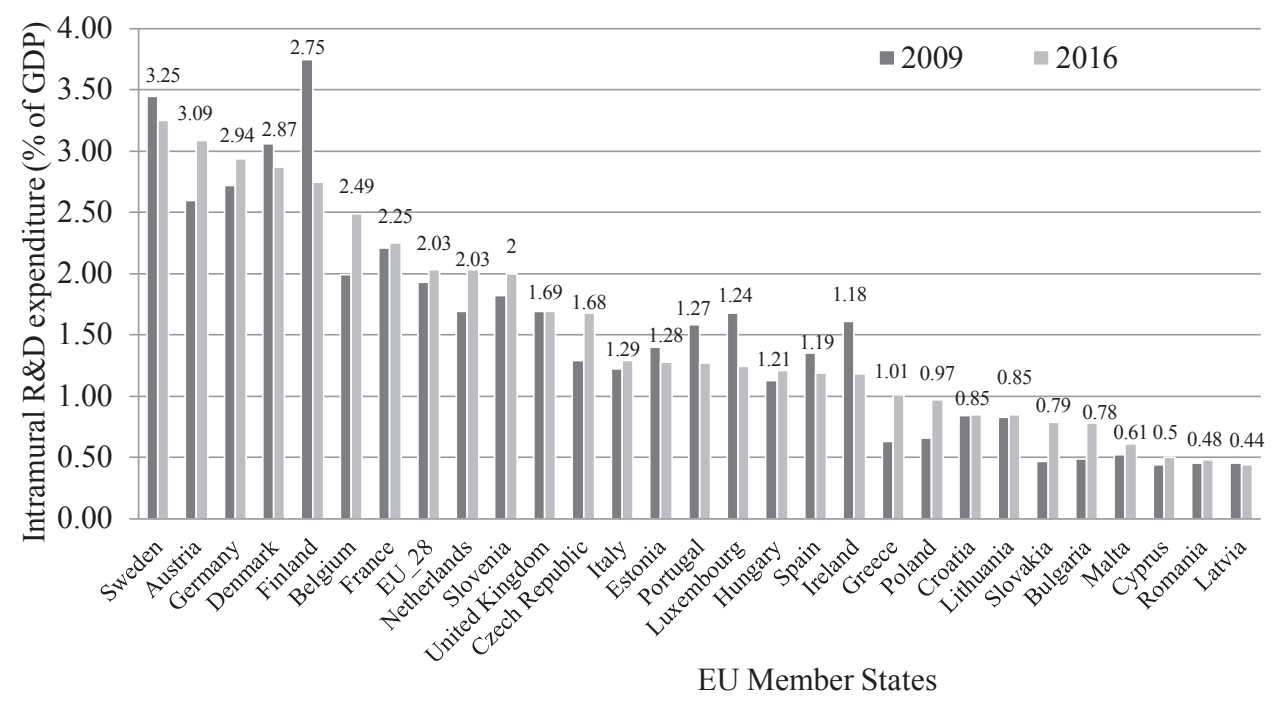

Fig. 1. Intramural R\&D expenditure in the EU Member States in 2016 vs 2009.

Source: own elaboration based on [Eurostat, Intramural R\&D expenditure (GERD) by sectors of performance [rd_e_gerdtot], access: 20.05.2018].

According to the data published by the Central Statistical Office, in 2016 budget funds constituted more than one third (36.0\%) of internal expenditure on R\&D. The largest share of the funds was allocated to the higher education sector $-69.9 \%$. More than a half $(55.2 \%)$ of internal expenditure came from the surveyed entities' own funds, of which $94.1 \%$ constituted the enterprise sector's own expenditure. Funds from abroad covered $5.5 \%$ of internal expenditure on $\mathrm{R} \& \mathrm{D}$, of which $67.0 \%$ was allocated to specialised research entities such as universities and research institutes [GUS and US in Szczecin 2018, p. 27].

Many researchers emphasise that for the development of the economy, funds spent on $\mathrm{R} \& \mathrm{D}$ in enterprises are of particular importance, as this expenditure is usually a guarantee of the faster commercialisation of research results. In reference to the widespread opinion that there is no competitive economy without competitive enterprises, some attention was paid to the allocation of R\&D expenditure in manufacturing enterprises.

In the years 2009-2016, expenditure on research and development in manufacturing enterprises increased from PLN 2022.0 to PLN 4844.1 million (an increase of 140\%) and came from various sources. The above-presented expenditure expressed in 2009 constant prices indicates that the average annual expenditure on R\&D increased by $13.2 \%$. In 2016 the most important were the enterprises' own financial resources, which constituted $85.4 \%$ of total R\&D expenditure, followed by funds from the state budget $-9.6 \%$ and foreign funds - approximately $5 \%$. 
The structure of distribution of $R \& D$ expenditure in 2016 among the individual divisions of manufacturing is strongly diversified. The following divisions have the highest share in the total value of expenditure on R\&D: manufacture of motor vehicles, trailers and semi-trailers (32.3\%), manufacture of fabricated metal products $(12.8 \%)$, manufacture of electrical equipment $(8.9 \%)$, as well as the manufacture of basic pharmaceutical substances and medicines and other pharmaceutical products (7.4\%). In other divisions the share of these outlays does not exceed $7 \%$. The smallest percentage, below $1 \%$, of total $\mathrm{R} \& \mathrm{D}$ expenditure is allocated to manufacture of clothing $(0.01 \%)$ as well as the manufacture of leather and leather products $(0.03 \%)$ [GUS 2017, p. 471].

The increase in expenditure on research and development activity incurred by entrepreneurs in the analysed period shows that the Polish industry is convinced of the need to invest in $R \& D$, and it seems that one can expect a further increase in these outlays in the future.

\section{Assessment of the relationship between innovations and the competitiveness of manufacturing divisions}

\subsection{The scope of data and research method}

An attempt to provide a quantitative description of the impact of R\&D expenditure on competitiveness has been made for three selected characteristics defining the competitiveness of manufacturing enterprises: sold production, gross value added and labour productivity. The study makes use of statistical data published by the Central Statistical Office on the amount of particular types of expenditure broken down by individual divisions of manufacturing (Section $\mathrm{C}$ of the Polish Classification of Activities - PKD) in the years 2009-2016. According to the Polish Classification of Activities, the study covers manufacturing divisions (Section C) at the two-digit level of aggregation (Table 2).

Table 2. The Polish Classification of Activities - manufacturing divisions (Section C)

\begin{tabular}{|c|l|c|l|}
\hline PKD & \multicolumn{1}{|c|}{ Division name } & PKD & \multicolumn{1}{|c|}{ Division name } \\
\hline 1 & \multicolumn{1}{|c|}{2} & 3 & \multicolumn{1}{|c|}{4} \\
\hline 10 & Manufacture of food products & 22 & $\begin{array}{l}\text { Manufacture of rubber and plastic } \\
\text { products }\end{array}$ \\
\hline 11 & Manufacture of beverages & 23 & $\begin{array}{l}\text { Manufacture of other non-metallic } \\
\text { mineral products }\end{array}$ \\
\hline 12 & Manufacture of tobacco products & 24 & Manufacture of metals \\
\hline 13 & Manufacture of textiles & 25 & $\begin{array}{l}\text { Manufacture of fabricated metal } \\
\text { products }\end{array}$ \\
\hline 14 & Manufacture of clothing & 26 & $\begin{array}{l}\text { Manufacture of computers, electronic } \\
\text { and optical products }\end{array}$ \\
\hline
\end{tabular}




\begin{tabular}{|c|l|c|l|}
\hline 1 & \multicolumn{1}{|c|}{2} & 3 & \multicolumn{1}{|c|}{4} \\
\hline 15 & Manufacture of leather and related products & 27 & Manufacture of electrical equipment \\
\hline 16 & $\begin{array}{l}\text { Manufacture of products of wood and cork, } \\
\text { articles of straw and plaiting materials }\end{array}$ & 28 & $\begin{array}{l}\text { Manufacture of machinery and } \\
\text { equipment }\end{array}$ \\
\hline 17 & Manufacture of paper and paper products & 29 & $\begin{array}{l}\text { Manufacture of motor vehicles, trailers } \\
\text { and semi-trailers }\end{array}$ \\
\hline 18 & $\begin{array}{l}\text { Printing and reproductions of recorded } \\
\text { media }\end{array}$ & 30 & $\begin{array}{l}\text { Manufacture of other transport } \\
\text { equipment }\end{array}$ \\
\hline 19 & $\begin{array}{l}\text { Manufacture and processing of coke and } \\
\text { refined petroleum products }\end{array}$ & 31 & Manufacture of furniture \\
\hline 20 & $\begin{array}{l}\text { Manufacture of chemicals and chemical } \\
\text { products }\end{array}$ & 32 & Other manufacturing \\
\hline 21 & $\begin{array}{l}\text { Manufacture of basic pharmaceutical } \\
\text { substances and medicines and other } \\
\text { pharmaceutical products }\end{array}$ & 33 & $\begin{array}{l}\text { Repair, maintenance and installation } \\
\text { of machinery and equipment }\end{array}$ \\
\hline
\end{tabular}

Source: own elaboration based on the Polish Classification of Activities [https://stat.gov.pl/Klasyfikacje/doc/pkd_07/pdf/2_PKD-2007-schemat_2.pdf].

In the case of Manufacture of tobacco products (division 12), there were numerous data gaps for the years 2010-2013. Data for this division were not published due to the necessity of statistical confidentiality pursuant to the Act on Public Statistics. Similarly, there were no data for division 19 - Manufacture and processing of coke and refined petroleum products for the years of 2010-2013 and 2015. Therefore, both these divisions were not included in the further analysis.

The collected statistical data have the structure of the panel in which the base period is the calendar year and the objects are the divisions of manufacturing.

The most general model based on longitudinal data can be presented in the following form [Baltagi 2005, p. 11]:

$$
y_{i t}=\alpha_{i}+\mathbf{X}_{i t}^{\prime} \beta+\varepsilon_{i t},
$$

where: index $i=1, \ldots, N$ denotes an object, $t=1, \ldots, T$-period, while $\mathbf{X}_{\text {it }}^{\prime}$ is a vector of observations on the explanatory variables with $K$ coordinates. The use of such models requires that the following assumptions should be met: the expected value $E\left[\varepsilon_{i t}\right]=0$,

and the variance of the random component is constant, i.e. $E\left[\varepsilon_{i t}^{2}\right]=\sigma_{e}^{2}$.

In the case of panel data, two solutions are proposed that allow for the heterogeneity of the analysed objects: the application of the fixed effects model (FEM), or the recognition of individual effects as random, which leads to the random effects model (REM).

In the fixed effects model, $\alpha_{i}$ is a specific effect for the object, with the same distribution in groups and over time, with the mean equal to 0 and the variance equal to $\sigma_{\alpha}^{2}$. 
In the random effects model, $\alpha_{i}$ are treated as random variables. It is assumed that they are independent of random components $\alpha_{i t}$ The random component in this case looks as follows: $v_{i t}=\alpha_{i}+\varepsilon_{i t}, \alpha_{i}$ includes all the unobservable factors that are specific to a given object [Baltagi 2005, p. 12; Maddala 2006].

Testing the significance of individual effects in the FEM model comes down to the verification of the hypothesis: $H_{0}: \alpha_{1}=\alpha_{2} \ldots=\alpha_{n}=\alpha$, which means that effects specific to the objects do not occur. The following statistic is used to verify the null hypothesis [Dańska-Borsiak 2011, p. 44]:

$$
F=\frac{(R R S S-U R S S) /(N-1)}{U R S S /(N T-N-K)} .
$$

The statistic has Snedeckor's F-distribution with $N-1$ and N $(T-1)$ degrees of freedom. The RRSS is the sum of squares of OLS residuals for the model based on all the observations, while the URSS is the sum of residual squares for the model with isolated individual effects.

In the case of the random effects model, the significance of variance of individual effects is tested on the basis of the Langrange multiplier method. To test the null hypothesis

( $H_{0}: \sigma_{\alpha}^{2}=0$ against the alternative hypothesis $H_{1}: \sigma_{\alpha}^{2} \neq 0$ ), the following statistic is used:

$$
L M=\frac{N T}{2(T-1)}\left[\frac{\sum_{i}\left(\sum_{t} e_{i t}\right)^{2}}{\sum_{i} \sum_{t} e_{i t}^{2}}\right]^{2},
$$

where: $e_{i t}$ are the residuals of the model without isolated group effects.

The choice between the FEM and REM model is made using the Hausman test [Dańska-Borsiak 2011, p. 53; Hausman 1978]. The tested null hypothesis assumes that individual effects are independent of the explanatory variables and both estimators are unbiased. In this situation the estimator for the random effects model (REM) is considered as more effective. The test statistic $m$ has the $\chi^{2}$ distribution.

\subsection{Sold production model}

A starting point of the analysis of the impact of $R \& D$ expenditure on sold production was the two-factor production function [Welfe 2000] expanded by another factor - expenditure on R\&D [Hall, Mairesse 1992; Reikard 2011]. The impact of R\&D expenditure on the value of sold production may be manifested with some lag, which is why also $R \& D$ expenditure incurred a year or two years earlier was tested. The 
expenditure incurred two years prior proved to be statistically insignificant. Finally, the sold production model of manufacturing divisions took the following form:

$$
\begin{aligned}
& N a l_{-} S_{i t}=\alpha_{i}+\beta_{0}+\beta_{1} N a l_{-} \operatorname{Empl}_{i t}+\beta_{2} \mathrm{Nal}_{-} \operatorname{Inv}_{\operatorname{Exp}} \\
& +\beta_{3} \mathrm{Nal}_{-} R \& D_{i t}+\beta_{4} \mathrm{Nal}_{-} R \& D_{i, t-1}+\varepsilon_{i t},
\end{aligned}
$$

where: Nal_S $S p_{i t}$ - the natural logarithm of the value of sold production in PLN million at 2009 constant prices (the price index of manufacturing sold production was used for the data realignment) for the $i$-th industry division in the period $t ; \mathrm{Nal}_{-} \mathrm{Empl}_{i t}$ - the natural logarithm of the average employment in thousands of persons for the $i$-th division of industry in the year $t ; \mathrm{Nal}_{\text {In }} \operatorname{In} \operatorname{Exp}_{i t}$ - the natural logarithm of investment expenditure in PLN million at 2005 constant prices (the CSO index of investment prices was used for the data realignment); $N a l_{-} R \& D_{i t}$ - the natural logarithm of R\&D expenditure in PLN million at 2005 constant prices (the CSO GDP price index was used for the data realignment); $N a l_{-} R \& D_{i, t-1}-$ the natural logarithm of R\&D expenditure over the period $t-1 ; \alpha_{i}-$ a specific individual effect, constant over time for a given division, variable between divisions.

The use of the Cobb-Douglas production function enables the interpretation of parameter evaluations in terms of the elasticity of production indices in relation to the inputs of individual production factors. The data used cover the period 20062016 for 21 divisions of manufacturing.

The results of estimating the parameters of the FEM and REM models for the value of sold production, including R\&D expenditure, are presented in Table 3.

The results of the conducted research confirm the impact of basic production factors on manufacturing sold production. The results of the estimation of both the FEM model and the REM model allow us to state that the size of employment and investment expenditure are positively and significantly in statistical terms correlated with the value of sold production. The impact of R\&D expenditure of the analysed manufacturing divisions on their production expressed in terms of value was also statistically significant. An important determinant of sold production is not only the current expenditure but also the expenditure in the year preceding the period considered. This is shown in both versions of the model. The parameter evaluations for the explanatory variables presented in Table 3 are very similar in both versions of the model. It is also worth noting that the individual effects of the FEM and REM models are statistically significant, which confirms the existence of unobservable individual effects specific to a given division of manufacturing. Due to the results of the Hausman test indicating that the estimator of the REM model was not consistent, further analysis was limited to the results of the fixed effects model.

According to the obtained results, a $1 \%$ increase in each of the two basic production factors results in an average increase in the value of sold production of respectively $0.996 \%$ in the case of employment and $0.169 \%$ in the case of investment expenditure. 
Table 3. Results of estimating the parameters of the FEM and REM models for the value of sold production in manufacturing ( $\left.N a l \_S p\right)$

\begin{tabular}{|c|c|c|c|c|c|c|}
\hline \multirow{2}{*}{ Variable } & $\begin{array}{c}\text { Parameter } \\
\text { estimate }\end{array}$ & $t$-statistic & $p$-value & $\begin{array}{c}\text { Parameter } \\
\text { estimate }\end{array}$ & $t$-statistic & $p$-value \\
\hline & \multicolumn{3}{|c|}{ FEM model } & \multicolumn{3}{|c|}{ REM model } \\
\hline Nal_Empl & 0.9969 & 7.0591 & 0.000 & 0.5413 & 0.5413 & 0.000 \\
\hline Nal_InvExp & 0.1686 & 4.8084 & 0.000 & 0.2611 & 7.4808 & 0.000 \\
\hline Nal_R\&D & 0.0373 & 3.2494 & 0.001 & 0.0299 & 2.3774 & 0.017 \\
\hline Nal_R\&D $D_{i t-1}$ & 0.0443 & 3.6738 & 0.001 & 0.0373 & 2.8356 & 0.005 \\
\hline Constant & 4.5252 & 8.5349 & 0.000 & 5.8640 & 18.7222 & 0.000 \\
\hline $\mathrm{R}^{2}$ & \multicolumn{3}{|c|}{0.993} & \multicolumn{3}{|c|}{0.740} \\
\hline $\begin{array}{l}\text { Within } \\
\text { R-squared }\end{array}$ & \multicolumn{3}{|c|}{0.679} & \multicolumn{3}{|c|}{-} \\
\hline $\begin{array}{l}\text { Evaluation } \\
\text { of the } \\
\text { significance of } \\
\text { group effects }\end{array}$ & \multicolumn{3}{|c|}{$\begin{array}{c}F=105.411 \\
(p=0.000)\end{array}$} & \multicolumn{3}{|c|}{$\begin{aligned} L M & =263.763 \\
(p & =0.000)\end{aligned}$} \\
\hline Hausman test & \multicolumn{6}{|c|}{$\begin{array}{c}m=44.8354 \\
(p=0.000)\end{array}$} \\
\hline
\end{tabular}

Source: own calculations based on CSO data.

On the other hand, a $1 \%$ increase in the current R\&D expenditure results in a $0.037 \%$ increase in sold production. The expenditure on R\&D lagged by one period has a slightly higher significance $(0.044 \%)$ for the production process.

\subsection{Gross value-added model}

Similarly as in the case of sold production, a starting point for gross value-added analyses was the Cobb-Douglas production function, taking into account an additional factor in the form of R\&D expenditure (current and lagged). Also in this case, the expenditure incurred two years earlier proved to be statistically insignificant. Bearing in mind the above-mentioned information, the following value-added model was used in the study:

$$
\begin{gathered}
\mathrm{Nal} \mathrm{GVA}_{i t}=\alpha_{i}+\beta_{0}+\beta_{1} \mathrm{Nal}_{-} \mathrm{Empl}_{i t}+\beta_{2} \mathrm{Nal}_{-} \mathrm{InvExp}_{i t} \\
+\beta_{3} \mathrm{Nal} \mathrm{I}_{-} \mathrm{R} \& D_{i t}+\beta_{4} \mathrm{Nal} \mathrm{I}_{-} \mathrm{R} \& D_{i, t-1}+\varepsilon_{i t},
\end{gathered}
$$

where: Nal_GVA ${ }_{i t}$ - the natural logarithm of gross value added in PLN million at 2009 constant prices (the CSO GDP price index was used for the data realignment) for the $i$-th industry division in the year $t$. The other designations are the same as in the sold production model. 
The results of the estimation of the value-added model in which the role of production factors is played by the size of employment, the volume of investment expenditure and the amount of expenditure on research and development (R\&D) activity are presented in Table 4.

Table 4. Results of estimating the parameters of the FEM and REM models for value-added in manufacturing (Nal_GVA)

\begin{tabular}{|c|c|c|c|c|c|c|}
\hline \multirow[t]{2}{*}{ Variable } & $\begin{array}{c}\text { Parameter } \\
\text { estimate }\end{array}$ & $t$-statistic & $p$-value & $\begin{array}{c}\text { Parameter } \\
\text { estimate }\end{array}$ & $t$-statistic & $p$-value \\
\hline & \multicolumn{3}{|c|}{ FEM model } & \multicolumn{3}{|c|}{ REM model } \\
\hline Nal_Empl & 1.0286 & 5.515 & 0.001 & 0.4185 & 6.4389 & 0.000 \\
\hline Nal_InvExp & 0.1941 & 3.350 & 0.000 & 0.3408 & 7.5011 & 0.000 \\
\hline$A l(R \& D)_{t}$ & 0.0472 & 2.488 & 0.001 & 0.0307 & 1.6800 & 0.000 \\
\hline$A l(R \& D)_{t-1}$ & 0.0517 & 2.596 & 0.014 & 0.0364 & 1.9253 & 0.093 \\
\hline Constant & 1.7827 & 2.035 & 0.044 & 4.5784 & 15.2956 & 0.054 \\
\hline R-squared & \multicolumn{3}{|c|}{0.975} & \multicolumn{3}{|c|}{0.873} \\
\hline $\begin{array}{l}\text { Within } \\
\text { R-squared }\end{array}$ & \multicolumn{3}{|c|}{0.537} & \multicolumn{3}{|c|}{-} \\
\hline $\begin{array}{l}\text { Evaluation of } \\
\text { the significance } \\
\text { of individual } \\
\text { effects } \\
\text { (value of test } \\
\text { statistic) }\end{array}$ & \multicolumn{3}{|c|}{$\begin{array}{l}F=20.934 \\
(p=0.000)\end{array}$} & \multicolumn{3}{|c|}{$\begin{aligned} L M & =205.167 \\
(p & =0.000)\end{aligned}$} \\
\hline Hausman test & \multicolumn{6}{|c|}{$\begin{array}{l}m=19.831 \\
(p=0.000)\end{array}$} \\
\hline
\end{tabular}

Source: own calculations based on CSO data.

When assessing the impact of basic production factors on the manufacturing value added, a significant and consistent with the expectations relationship between the analysed variables was established. Both employment and investments have a positive impact on value-added in manufacturing, which is indicated by the results of the FEM and REM models. It should be emphasised that individual effects related to the specificity of a given manufacturing division proved to be significant. However, as in the case of the sold production model, the Hausman test pointed to the superiority of the fixed effects model. The results for the FEM model presented in Table 4 allow us to state that a $1 \%$ increase in the number of employees contributes to a $1.02 \%$ increase in the gross value added, while a $1 \%$ increase in expenditure is associated with an increase of on average $0.194 \%$.

Expenditure (current and lagged) on research and development activity, which is the main subject of the analyses conducted, is important for shaping the gross valueadded of manufacturing enterprises. A one percent increase in the current R\&D 
expenditure contributes to the increase of gross value added of sold production of on average $0.047 \%$, or $0.05 \%$ lagged by one period.

\subsection{Labour productivity model}

In the presented study, labour productivity was characterised as a quotient of the gross value added and the size of employment in the manufacturing divisions.

The following model was used in the labour productivity analysis:

$$
\begin{gathered}
\text { Nal_ }(\text { GVA / Empl })_{i t}=\alpha_{i}+\beta_{0}+\beta_{1} N_{a l} I_{-} \operatorname{InvExp} p_{i t} \\
\quad+\beta_{2} \mathrm{Nal}_{-} R \& D_{i t}+\beta_{3} \mathrm{Nal}_{-} R \& D_{i, t-1}+\varepsilon_{i t},
\end{gathered}
$$

where: Nal_(GVA/Empl $)_{i t}$ - the natural logarithm of labour productivity understood as the ratio of gross value added to the number of people working in the $i$-th manufacturing division in year $t$.

The results of the estimation of the FEM and REM models for labour productivity are presented in Table 5.

Table 5. Results of estimating the parameters of the FEM and REM models for labour productivity

\begin{tabular}{|c|c|c|c|c|c|c|}
\hline \multirow[t]{2}{*}{ Variable } & $\begin{array}{c}\text { Parameter } \\
\text { estimate }\end{array}$ & $t$-statistic & $p$-value & $\begin{array}{c}\text { Parameter } \\
\text { estimate }\end{array}$ & t-statistic & $p$-value \\
\hline & \multicolumn{3}{|c|}{ FEM model } & \multicolumn{3}{|c|}{ REM model } \\
\hline Nal_InvExp & 0.2279 & 4.4622 & 0.000 & 0.2096 & 4.3249 & 0.000 \\
\hline$N a l \_(\mathrm{R} \& \mathrm{D})_{t}$ & 0.0453 & 2.3907 & 0.018 & 0.0421 & 2.2422 & 0.025 \\
\hline$N a l \_(\mathrm{R} \& \mathrm{D})_{t-1}$ & 0.0506 & 2.5395 & 0.012 & 0.0476 & 2.4240 & 0.015 \\
\hline Constant & 2.7811 & 8.4843 & 0.000 & 2.9416 & 8.8866 & 0.000 \\
\hline R-squared & \multicolumn{3}{|c|}{0.952} & \multicolumn{3}{|c|}{0.9060} \\
\hline Within R-squared & \multicolumn{3}{|c|}{0.359} & \multicolumn{3}{|c|}{-} \\
\hline $\begin{array}{l}\text { Evaluation of the } \\
\text { significance of } \\
\text { individual effects } \\
\text { (value of test statistic) }\end{array}$ & \multicolumn{3}{|c|}{$\begin{array}{l}F=20.934 \\
(p=0.000)\end{array}$} & \multicolumn{3}{|c|}{$\begin{aligned} L M & =205.167 \\
(p & =0.000)\end{aligned}$} \\
\hline Hausman test & \multicolumn{6}{|c|}{$\begin{array}{c}m=5,90247 \\
(p=0.116)\end{array}$} \\
\hline
\end{tabular}
in manufacturing - Nal_(GVA/Empl)

Source: own calculations based on CSO data.

The results of the FEM and REM models confirm the significant and positive impact of R\&D expenditure on labour productivity. In contrast to the previous two models, the Hausman test indicates the REM model. The obtained results for this model allow us to state that a $1 \%$ increase in the current $R \& D$ expenditure may 
result in labour productivity growth of on average $0.04 \%$. The impact of expenditure incurred in the $t-1$ period is also significant and positive. Its $1 \%$ increase results in an average productivity increase of $0.05 \%$.

\section{Conclusions}

The analyses carried out for the years 2009-2016 with the use of panel models confirm the positive impact of $\mathrm{R} \& \mathrm{D}$ expenditure on the competitiveness of manufacturing divisions understood alternatively as sold production, gross value added and labour productivity. The applied functional form of the models enables the interpretation of parameter evaluations in terms of flexibility of competitiveness indices with respect to the inputs of particular production factors, including expenditure on research and development. The impact of R\&D expenditure analysed in the study, expressed by the model parameter evaluation, is similar for all the three considered competitiveness measures - this applies both to the current expenditure and the expenditure incurred in the period preceding the analysed period. As the results of the analyses conducted indicate, the importance of current expenditure is slightly lower due to the time which must elapse from the moment of incurring expenditure on research and development activity until its measurable effects appear. In general, $R \& D$ expenditure is characterised by its long-term nature, and the costs of scientific research can often be recovered only after many years.

\section{Bibliography}

Baltagi B.H., 2005, Econometric Analysis of Panel Data, third edition, John Wiley \& Sons, Ltd., Chichester, England.

Bassanini A., Scarpetta S., Hemmings P., 2001, Economic Growth: The Role of Policies and Institutions. Panel Data. Evidence from OECD Countries, OECD Economics Department Working Papers, p. 283.

Bouis R., Duval R., Murtin F., 2011, The Policy and Institutional Drivers of Economic Growth Across OECD and Non-OCED Economies. New Evidence from Growth Regressions, OECD Economics Department Working Papers, p. 843.

Dańska-Borsiak B., 2011, Dynamiczne modele panelowe w badaniach ekonomicznych, Wydawnictwo Uniwersytetu Łódzkiego, Łódź, pp. 40-51.

Eurostat, Intramural $R \& D$ expenditure (GERD) by sectors of performance, [rd_e_gerdtot], access: 20.05.2018.

GUS, 2009, Nauka i technika, Warszawa.

GUS, 2017, Rocznik Statystyczny Przemysłu 2017, Warszawa.

GUS and US in Szczecin, 2016, Nauka i technika w 2015 r., Warszawa.

GUS and US in Szczecin, 2017, Działalność badawcza i rozwojowa w Polsce w 2016, Warszawa.

GUS and US in Szczecin, 2018, Nauka i technika w 2016 r., Warszawa.

Hall B., Mairesse J., 1992, Exploring the Relationship Between R\&D and Productivity in French Manufacturing Firms, NBER Working Paper, no. 3956. 
Hausman J.A., 1978, Specification Tests in Econometrics, Econometrica, vol. 46, Issue 6, pp. 1251-1271. Maddala G.S., 2006, Ekonometria, PWN, Warszawa.

Porter M., 1990, The Competitive Advantage of Nations, The Free Press, New York.

Reikard G., 2011, Total factor productivity and $R \& D$ in the production function, International Journal of Innovation and Technology Management, vol. 08, no. 04.

Walczak E., 2012, Czynniki wzrostu gospodarczego w krajach Unii Europejskiej, Wiadomości Statystyczne, $\mathrm{nr} 4$.

Welfe W., 2000, Empiryczne modele wzrostu gospodarczego, Ekonomista, nr 4, Warszawa, pp. 483-497. Witkowski B., Weresa M.A., 2006, Wpływ innowacji na konkurencyjność branż polskiego przemysłu, [in:] Polska. Raport o konkurencyjności 2006. Rola innowacji w kształtowaniu przewag konkurencyjnych, Weresa M.A. (ed.), Instytut Gospodarki Światowej SGH, Warszawa.

\section{ZNACZENIE NAKŁADÓW NA DZIALALNOŚĆ BADAWCZO-ROZWOJOWĄ DLA KONKURENCYJNOŚCI PRZEDSIĘBIORSTW PRZETWÓRSTWA PRZEMYSLOWEGO W POLSCE. ZASTOSOWANIE MODELI PANELOWYCH}

Streszczenie: We współczesnych badaniach i dyskusjach ekonomicznych dużo uwagi poświęca się zagadnieniom dotyczącym powiązań między konkurencyjnością a działalnością badawczo-rozwojową $(\mathrm{B}+\mathrm{R})$. Pomiar i ocena wpływu efektów działalności badawczo-rozwojowej są wyjątkowo trudne, ale jednocześnie bardzo ważne, szczególnie dla władz określających poziom nakładów na B+R i sposób wydatkowania środków publicznych oraz dla przedsiębiorstw oceniających spodziewane zyski z działalności B+R. Celem artykułu jest próba ilościowego opisu wpływu nakładów na badania i rozwój na trzy wybrane charakterystyki określające konkurencyjność przedsiębiorstw przetwórstwa przemysłowego (wartość dodaną brutto, produkcję sprzedaną i wydajność pracy). Analiza została przeprowadzona z użyciem modeli panelowych. W badaniu wykorzystano publikowane dane statystyczne Głównego Urzędu Statystycznego dla poszczególnych działów przetwórstwa przemysłowego (sekcja C PKD) w latach 2009-2016. Z przeprowadzonych analiz wynika, że nakłady na B+R stanowią istotną determinantę konkurencyjności analizowanych działów przetwórstwa przemysłowego.

Slowa kluczowe: nakłady na B+R, konkurencyjność, przetwórstwo przemysłowe, modele panelowe. 